\title{
AWARENESS OF MENSTRUAL HYGIENE AND FACTORS AFFECTING ITS PRACTICE AMONG ADOLESCENT GIRLS IN TWO SELECTED SENIOR SECONDARY SCHOOLS IN OGUN STATE, NIGERIA
}

\author{
Ajaegbu Victoria U. ${ }^{1}$, Okwuikpo Margaret I. .* , Famuyigbo Oreoluwa F. ${ }^{3}$, \\ Leslie Tabitha Amere ${ }^{4}$, Maitanmi Julius Olatade ${ }^{5}$ and Maitanmi Bukola Titilope ${ }^{6}$ \\ ${ }^{1}$ Public and Allied Health Department, Babcock University, Ilishan-Remo Ogun State, Nigeria \\ ${ }^{2}$ Maternal and Child Health Department, Babcock University, Ilishan-Remo Ogun State, Nigeria \\ ${ }^{3}$ Babcock University Teaching Hospital, Ilishan-Remo Ogun State, Nigeria \\ ${ }^{4}$ Community Health Nursing Department, Babcock University, Ilishan-Remo Ogun State, Nigeria \\ ${ }^{5}$ Community Health Nursing Department, Babcock University, Ilishan-Remo Ogun State, Nigeria \\ ${ }^{6}$ Mental Health Nursing Department, Babcock University, Ilishan-Remo Ogun State, Nigeria
}

*Corresponding Author E-mail: okwuikpom@babcock.edu.ng

\author{
Cite this article: \\ Ajaegbu V.U., Okwuikpo \\ M.I., Famuyigbo O.F., Leslie \\ T.A., Maitanmi J.O., \\ Maitanmi B.T. (2021), \\ Awareness of Menstrual \\ Hygiene and Factors Affecting \\ its Practice Among \\ Adolescent Girls in Two \\ Selected Senior Secondary \\ Schools in Ogun State, \\ Nigeria. African Journal of \\ Health, Nursing and \\ Midwifery 4(2), 76-87. DOI: \\ 10.52589/AJHNM- \\ MXRNYNCJ.
}

\section{Manuscript History \\ Received: 30 March 2021 \\ Accepted: 28 April 2021 \\ Published: 11 May 2021}

Copyright $\odot 2020$ The Author(s). This is an Open Access article distributed under the terms of Creative Commons AttributionNonCommercial-NoDerivatives 4.0 International (CC BY-NC-ND 4.0), which permits anyone to share, use, reproduce and redistribute in any medium, provided the original author and source are credited.
ABSTRACT: Background: In Africa, menstrual hygiene and its practices are still clouded by taboos and sociocultural restrictions, ignorance and illiteracy so that menstruation is viewed in a base manner, and considered dirty and filthy, which requires the isolation of the woman from some normal daily activities. Thus, menstrual hygiene involves the conditions and activities that promote and preserve health during menstruation. This study assessed the awareness of menstrual hygiene and factors affecting its practice among adolescent girls in two selected senior secondary schools in Ogun state, Nigeria. Method: The study utilized quantitative cross-sectional survey design. Purposive sampling technique was used in selecting 150 respondents for the study in the two selected senior secondary schools. Descriptive statistics, correlation and T-test fixed at 0.05 significance level was conducted to give statistical responses to the research hypotheses using SPSS version 21. Result: The result showed that adolescent girls in Babcock University High School (BUHS) and Remo High School (RHS) had advanced knowledge of menstrual hygiene and they had moderate practices of menstrual hygiene, but there were factors like religion and lack of conducive facilities affecting the effective practice among adolescent girls. Furthermore, respondents' knowledge on menstrual hygiene had no significant positive relationship with practices of menstrual hygiene among adolescent girls in private schools and those in public schools $(r=.022, p>.01)$. There was no significant difference between adolescent girls in private and public schools on practice of menstrual hygiene. Conclusion: Adolescent girls in BUHS and RHS had advanced knowledge of menstrual hygiene but moderate menstrual hygiene practices. This may be as a result of factors such as religion and lack of conducive facilities that hinder the effective practice among adolescent girls as identified in the study. Among other recommendations, the school administrations are advised to provide more conducive and appealing facilities for adolescent girls to practise good menstrual hygiene.

KEYWORDS: Awareness, Practice, Menstrual Hygiene, Adolescent 


\section{INTRODUCTION}

Menstruation is a normal physiological process that occurs in females during their reproductive age. The onset of menstruation is at puberty. There is no definite definition of menstrual hygiene; however, on a breakdown, hygiene can be defined as those conditions and activities that promote and preserve health while menstruation can be defined as the cyclical shedding of the inner lining of the uterus - the endometrium - under the control of hormones of the hypothalamo-pituitary axis (Uzoma-Aniebue, Nonyelum-Aniebue \& Ogochukwu-Nwankwo, 2009). Menstrual hygiene involves the conditions and activities that promote and preserve health during menstruation. Girls usually get to their stage of puberty between age 8 and age 13 , and about two and a half years after a girl's breast develops, she usually experiences her first period. Most girls start having their menstruation between the ages of 11 and 15, usually always after their peak growth rate in height. The first menstrual period a girl experiences is called menarche.

Adolescence, according to WHO, is identified as the period in human growth and development that occurs after childhood and before adulthood, from age 10-19. A menstrual cycle is defined as a period between the first days of menstrual period to the onset of the next menstrual period. Averagely, the cycle is about 28 days and the period lasts for 3-5 days. Menstrual hygiene practices can be influenced by the quality of information gathered, cultural and religious beliefs, environmental factors like location, and the race. Maintaining cleanliness and tidiness during the menstrual cycle is a big problem especially when the information on menstruation and reproductive health is poor. Poor environmental factors negatively influence menstrual hygiene practices.

In Africa, Nigeria specifically, among the Ijaw people of the South South, Bayelsa state, information on adolescent menstrual hygiene and its proper practice are scarce and have not been accessible by adolescent girls (Adika, 2011). Lawan, Nafisa and Aisha (2010) reported differences in the levels of knowledge between urban and rural school girls. The study reported that the differences were connected to their different levels of exposure to information about reproductive health, as urban school girls were found to be more exposed to media-borne information than girls in rural schools. The study reported that urban girls applied better hygienic practices than rural girls. Contrary to the above findings on knowledge, a study carried out in Eastern Nigeria indicated an adequate level of knowledge of menstruation and menstrual hygiene among girls in rural schools (Nkandi, 2011).

Yadav, Joshi, Poudel and Pandeya, (2017) reported in their study on menstrual hygiene management among the adolescent girls that $67.4 \%$ have a fair knowledge, $26.4 \%$ have a good knowledge and only $40 \%$ were using good practices.

Parents are among the contributors to the lack of information among adolescent girls. The refusal of parents to communicate with their daughters about sensitive issues like this has left a great vacuum in the female children's hygienic management and practices, and of course it is particularly noticed in the rural communities and among uneducated parents (Mudey, Keshwani, Mudey, \& Goyal, 2010). On the part of culture and religion, there are different views about menstruation. In Nigeria, religion has been identified as one of the factors that affect menstrual practices. Guterman, Mehta and Gibbs, (2008) reported that the Christian denomination excludes menstruating women from some activities in the church, such as the holy communion. Also, it has been reported that in the Muslim community, menstruating 
women are to be avoided by men; they should be left alone until they are cleaned and have been purified (Guterman et al., 2008). Taboos surrounding menstruation exclude women and girls from many aspects of social and cultural life as well as menstrual hygiene services. Such taboos include not being able to touch animals, water points or food that others will eat, and exclusion from religious rituals, the family home and sanitation facilities. As a result, women and girls are often denied access to water and sanitation when they need it most (Kamath, Ghosh, Lena \& Chandrasekaran, 2013).

Moreover, expense of commercial pads, lack of water and sanitation facilities at schools, and lack of gender specific toilets or private rooms for changing sanitary pads are some of the factors that affect menstrual hygiene management (MHM) at the social, cultural and economic levels (Loughborough University, 2012).

Poor menstrual hygiene practices allow for a great breed of infectious disease-causing microbes which can lead to morbidity or mortality of the girl child sooner or later. Also, poor menstrual hygiene and its practices have resulted in poor health outcomes or results and poor health status of the adolescent girl (Uzochukwu, Patricia \& Theophilus 2009). Furthermore, unhygienic practices during menstruation lead to reproductive tract infections of various kinds as well as other gynaecological issues (Shanbhag et al., 2012). Additionally, mismanagement of menstrual hygiene affects women's private and social lives in many ways (Ahmed \& Yesmin, 2008). Many girls who do not attend school or are unable to concentrate properly in the classroom end up having poor performances in their examinations (Alam, Luby, Halder, Islam., Opel, Shoab, ... \& Unicomb, 2017).). On the other hand, good knowledge of menstrual hygiene and practices reduces the risk of urinary and reproductive tract infections and complications (Kamaljit, Arora, Singh, \& Neki, 2012). Moreover, the expense of commercial pads, lack of water and sanitation facilities in schools, and lack of gender specific toilets or private rooms for changing sanitary pads are some of the factors that affect menstrual hygiene management (MHM) at the social, cultural and economic levels (Loughborough University, 2012).

Sadly, attention on issues relating to menstrual hygiene has been insufficient and not appropriately addressed, and its practices have not been properly dealt with yet (WaterAid, 2009). Awareness about menstruation, menstrual hygiene and its practices among adolescents is low and not properly communicated. A study from UNICEF revealed that 1 out of 3 girls in South Asia know nothing about menstruation prior to experiencing it while $48 \%$ of girls in Iran and $10 \%$ of girls in India still believe that menstruation is a disease (WaterAid, 2013). Schools, on the other hand, have paid little or no attention to increasing the knowledge, enlightening students and empowering them about methods and ways to improve menstrual hygiene practices. Adolescent girls that are still ignorant of hygienic practices or unwilling to take up proper management end up having serious adverse health challenges (Dasgupta \&Sarkar, 2008).

Thus, it is important for adolescents to have necessary knowledge, amenities and a good cultural environment to manage menstruation hygienically and with dignity. It is very essential to prepare adolescent girls adequately before puberty or menarche on menstruation, its hygiene and proper management or practices. This research was carried out to assess the level of awareness of menstrual hygiene and its practices among senior secondary school girls in two selected secondary schools in Ogun state, Nigeria. 


\section{Research Questions}

1. What is the level of awareness of menstrual hygiene among adolescent girls of senior secondary schools?

2. What are the menstrual hygiene practices of adolescent girls in private schools and that of adolescent girls in public schools?

3. What are the factors affecting menstrual hygiene practices among adolescent girls of senior secondary schools?

\section{Research Hypotheses}

1. There is no significant relationship between awareness of menstrual hygiene and its practices among adolescent girls.

2. There is no significant difference in the practice of menstrual hygiene among adolescent girls based on type of school (private or public schools).

\section{Methods}

The study adopted a quantitative cross-sectional survey design. The aim of the design was to provide data on the entire population under study. The study was carried out in two different schools in Ogun state, Nigeria-Babcock University High School and Remo High School. The study population consisted of adolescent girls who had started menstruating in the two selected secondary schools (BUHS and RHS). This study implored purposeful sampling technique. Simple random selection under strict monitoring was used to select the participants.

Sample size was determined using Yamane's (1973) formula:

$$
\begin{aligned}
& \mathrm{n}=\frac{\mathrm{N}}{1+\mathrm{N}(\mathrm{R})^{2}} \\
& \mathrm{n}=150.4 \\
& \text { where } \mathrm{N}=\text { total population size } \\
& \qquad \mathrm{n}=\text { sample size } \\
& \mathrm{R}=\text { level of precision }(0.05)
\end{aligned}
$$

Table 1: Population Determination in the Two Schools

\begin{tabular}{|l|l|l|l|l|}
\hline Name of school & $\begin{array}{l}\text { Population of } \\
\text { girls in SSS1 }\end{array}$ & $\begin{array}{l}\text { Population of } \\
\text { girls in SSS2 }\end{array}$ & $\begin{array}{l}\text { Population of } \\
\text { girls in SSS3 }\end{array}$ & Total \\
\hline $\begin{array}{l}\text { Babcock University } \\
\begin{array}{l}\text { High School } \\
\text { Remo High School }\end{array}\end{array}$ & 40 & 43 & 35 & 118 \\
& 45 & 40 & 38 & 123 \\
\cline { 3 - 5 }
\end{tabular}


Ethical clearance was obtained from Babcock University Health and Reach Ethics Committee before going to the field to protect the participants' rights. Informed consent was also given through verbal communication and interaction with the students. Participants were allowed to voluntarily choose to participate.

\section{RESULT}

Table 2: Demographic Information of participants

\begin{tabular}{|c|c|c|c|c|c|c|}
\hline & \multicolumn{4}{|l|}{$\mathrm{N}=150$} \\
\hline & & & \multicolumn{2}{|c|}{$\begin{array}{c}\text { Babcock University } \\
\text { High School }\end{array}$} & \multicolumn{2}{|c|}{$\begin{array}{l}\text { Remo High } \\
\text { School }\end{array}$} \\
\hline $\mathbf{S} / \mathbf{N}$ & \multicolumn{2}{|l|}{ Items } & Frequency & $\%$ & Frequency & $\%$ \\
\hline \multirow[t]{3}{*}{1} & \multirow[t]{3}{*}{ Age } & 12-14 years & 53 & 70.7 & 3 & 4.0 \\
\hline & & 15-17 years & 22 & 29.3 & 66 & 88.0 \\
\hline & & 18-20 years & - & $-?$ & 6 & 8.0 \\
\hline \multirow[t]{3}{*}{2} & \multirow[t]{3}{*}{ Class } & SSS1 & 31 & 41.3 & 75 & 100 \\
\hline & & SSS2 & 31 & 41.3 & $-?$ & - \\
\hline & & SSS3 & 13 & 17.3 & $-?$ & - \\
\hline \multirow[t]{2}{*}{3} & \multirow[t]{2}{*}{ Name of school } & Remo High School & 75 & 50 & & \\
\hline & & $\begin{array}{l}\text { Babcock University } \\
\text { High School }\end{array}$ & 75 & 50 & & \\
\hline \multirow[t]{2}{*}{4} & \multirow{2}{*}{$\begin{array}{l}\text { Are you the first } \\
\text { female child in } \\
\text { your family? }\end{array}$} & Yes & 39 & 52.0 & 37 & 49.3 \\
\hline & & No & 36 & 48.0 & 38 & 50.7 \\
\hline \multirow[t]{2}{*}{5} & \multirow{2}{*}{$\begin{array}{l}\text { Occupation of } \\
\text { parents }\end{array}$} & Vocational workers & 21 & 28.0 & 59 & 78.7 \\
\hline & & Civil servants & 54 & 72.0 & 16 & 21.3 \\
\hline \multirow[t]{2}{*}{6} & \multirow{2}{*}{$\begin{array}{l}\text { Have you started } \\
\text { your period? }\end{array}$} & Yes & 72 & 96.0 & 72 & 96.0 \\
\hline & & No & 3 & 4.0 & 3 & 4.0 \\
\hline
\end{tabular}

Table 2 presents demographic background information of the respondents. Majority (88.0\%) were between 15 and 17 years of age in Remo High School and 70.7\% were between 12 and 17 years in Babcock University High School. 41.3\% were in SSS1, 41.3\% were in SSS2 and 17.3\% were in SSS3 in Babcock University High School. 50\% of students of Remo High School and 50\% of students of Babcock University High School were chosen. Majority of their parents were vocational workers. Majority (96\% respectively) in both schools reported that they had started their periods. 
African Journal of Health, Nursing and Midwifery

ISSN: 2689-9418

Volume 4, Issue 2, 2021 (pp. 76-87)

www.abjournals.org

Table 3: Awareness of Menstrual Hygiene

\begin{tabular}{|l|l|l|l|l|l|}
\hline \multicolumn{2}{|l}{} & \multicolumn{2}{l|}{$\begin{array}{l}\text { Babcock University } \\
\text { High School }\end{array}$} & \multicolumn{2}{l|}{ Remo High School } \\
\hline S/ & Items & Yes & No & Yes & No \\
\cline { 3 - 6 } & F(\%) & F(\%) & F(\%) & F(\%) \\
\hline 1 & $\begin{array}{l}\text { Have you heard of the term } \\
\text { mensuration? }\end{array}$ & $72(96.0)$ & $3(4.0)$ & $\begin{array}{l}74 \\
(98.7)\end{array}$ & $1(1.3)$ \\
\hline 2 & $\begin{array}{l}\text { Menstrual hygiene can be good or } \\
\text { poor? }\end{array}$ & $74(98.7)$ & $1(1.3)$ & $\begin{array}{l}62 \\
(82.7)\end{array}$ & $13(17.3)$ \\
\hline 3 & $\begin{array}{l}\text { Good menstrual hygiene involves using } \\
\text { reusable cloth for pad during } \\
\text { menstruation? }\end{array}$ & $10(13.3)$ & $\begin{array}{l}65 \\
(86.7)\end{array}$ & $\begin{array}{l}21 \\
(28.0)\end{array}$ & $54(72.0)$ \\
\hline 4 & $\begin{array}{l}\text { Menstrual hygiene is those activities } \\
\text { during menstruation that promotes } \\
\text { health? }\end{array}$ & $67(89.3)$ & $8(10.7)$ & $\begin{array}{l}67 \\
(89.3)\end{array}$ & $8(10.7)$ \\
\hline 5 & $\begin{array}{l}\text { Poor menstrual hygiene practices can } \\
\text { cause sickness? }\end{array}$ & $67(89.3)$ & $8(10.7)$ & $\begin{array}{l}63 \\
(84.0)\end{array}$ & $12(16.0)$ \\
\hline 6 & $\begin{array}{l}\text { Using sanitary pad is a good menstrual } \\
\text { hygiene practice? }\end{array}$ & $74(98.7)$ & $1(1.3)$ & $\begin{array}{l}70 \\
(93.3)\end{array}$ & $5(6.7)$ \\
\hline
\end{tabular}

Table 3 presents information on awareness of menstrual hygiene. Majority of the students had heard of the term menstruation in Remo High School (RHS) and Babcock University High School (BUHS) $-98.7 \%$ and $96 \%$ respectively. $82.7 \%$ reported that menstrual hygiene can be good or poor in BUHS and $98.7 \%$ did same in RHS. For $86.7 \%$ and $72.0 \%$ in BUHS and RHS respectively, good menstrual hygiene does not involve using reusable cloth for pad during menstruation. $89.3 \%$ in both schools agreed that menstrual hygiene are those activities during menstruation that promote health. Also, $89.3 \%$ and $84 \%$ in BUHS and RHS respectively agreed that poor menstrual hygiene practices can cause sickness. Finally, 98.7\% in BUHS and 93.3\% in RHS reported that using sanitary pad is a good menstrual hygiene practice.

Table 4: Menstrual Hygiene Practices

\begin{tabular}{|l|l|l|l|l|l|}
\hline \multicolumn{5}{|c|}{$\begin{array}{l}\text { Babcock University } \\
\text { High School }\end{array}$} & \multicolumn{2}{l|}{ Remo High school } \\
\hline S/N & Items & Yes & No & Yes & No \\
\hline \multicolumn{7}{|l|}{} & What do you normally use during your period? \\
\hline 1 & Cloth towel & $1(1.3)$ & $74(98.7)$ & $9(12.0)$ & $66(88.0)$ \\
\hline 2 & Sanitary pads & $\begin{array}{l}61 \\
(81.3)\end{array}$ & $14(18.7)$ & $68(90.7)$ & $7(9.3)$ \\
\hline 3 & Menstrual cup & $5(6.7)$ & $70(93.3)$ & $4(5.3)$ & $71(94.7)$ \\
\hline 4 & Toilet paper & $\begin{array}{l}11 \\
(14.7)\end{array}$ & $64(85.3)$ & $7(9.3)$ & $68(90.7)$ \\
& & & & & \\
& & & & & \\
\hline
\end{tabular}




\begin{tabular}{|c|c|c|c|c|c|}
\hline & \multicolumn{5}{|c|}{ How many times do you take your bath when menstruating? } \\
\hline 5 & Once & $9(12.0)$ & $66(88.0)$ & $7(9.3)$ & $68(90.3)$ \\
\hline 6 & Two times & $\begin{array}{l}83 \\
(55.3) \\
\end{array}$ & $40(53.3)$ & $48(64.0)$ & $27(36.0)$ \\
\hline 7 & Three times & $\begin{array}{l}36 \\
(48.0) \\
\end{array}$ & $39(52.0)$ & $23(30.7)$ & $52(69.3)$ \\
\hline & \multicolumn{5}{|c|}{ How do you dispose used menstrual materials? } \\
\hline 8 & By burning & $\begin{array}{l}50 \\
(66.7)\end{array}$ & $25(33.3)$ & $13(17.3)$ & $62(82.7)$ \\
\hline 9 & By flushing in the toilet & $\begin{array}{l}19 \\
(25.3)\end{array}$ & $56(74.7)$ & 31 (41.3) & $44(58.7)$ \\
\hline 10 & By burying & $\begin{array}{l}34 \\
(45.3)\end{array}$ & $41(54.7)$ & $24(32.0)$ & $51(68.0)$ \\
\hline 11 & By washing and reusing & $2(2.7)$ & $73(97.3)$ & $12(16.0)$ & $63(84.0)$ \\
\hline & \multicolumn{5}{|c|}{ How often do you buy and use menstrual materials? } \\
\hline 12 & Once in a while & $2(2.7)$ & $73(97.3)$ & $28(37.3)$ & $47(62.7)$ \\
\hline 13 & Two times in a year & $1(1.3)$ & 74 (98.7) & $16(21.3)$ & $59(78.7)$ \\
\hline 14 & I reuse previous ones & $1(1.3)$ & 74 (98.7) & 75 & $(100)$ \\
\hline 15 & Alternatively & $9(12.0)$ & $66(88)$ & $30(40.0)$ & $45(60.0)$ \\
\hline 16 & Every month & $\begin{array}{l}65 \\
(86.7)\end{array}$ & $10(13.3)$ & $50(66.7)$ & $25(33.3)$ \\
\hline 17 & I do not buy materials & $\begin{array}{l}74 \\
(98.7)\end{array}$ & $1(1.3)$ & $15(20.0)$ & $60(80.0)$ \\
\hline 18 & $\begin{array}{l}\text { Do you stay away from all other } \\
\text { activities during your period? }\end{array}$ & $\begin{array}{l}21 \\
(28.0)\end{array}$ & $54(72.0)$ & $36(48.0)$ & $39(52.0)$ \\
\hline
\end{tabular}

Table 4 presents responses on menstrual hygiene practices. Majority of the students used sanitary pads $(81.3 \%$ and $90.7 \%)$ during their periods and took their baths two times $(55.3 \%$ and $64.0 \%$ ) in BUHS and RHS respectively when menstruating. Most disposed used menstrual materials by burning $(66.7 \%$ and $17.3 \%)$, flushing in the toilet $(25.3 \%$ and $41.3 \%)$ and by burying (45.3\% and 32.0\%) in BUHS and RHS respectively. Most of them often bought and used menstrual materials every month- $-86.7 \%$ in BUHS and $66.7 \%$ in RHS. Specifically, $28 \%$ and $48 \%$ in BUHS and RHS respectively reported that they stay away from all other activities during their periods.

Table 5: Factors Affecting Menstrual Hygiene Practices

\begin{tabular}{|l|l|l|l|l|l|}
\hline \multicolumn{2}{|l|}{} & \multicolumn{2}{l|}{$\begin{array}{l}\text { Babcock University } \\
\text { High School }\end{array}$} & \multicolumn{2}{l|}{ Remo High school } \\
\hline S/N & Items & Yes & No & Yes & No \\
\hline 1 & $\begin{array}{l}\text { In my family, we are forbidden from using } \\
\text { sanitary pad }\end{array}$ & $2(2.7)$ & $73(97.3)$ & $4(5.3)$ & $\begin{array}{l}71 \\
(94.7)\end{array}$ \\
\hline 2 & $\begin{array}{l}\text { My family only allows use of tissue paper } \\
\text { and cloth material when menstruating }\end{array}$ & $3(4.0)$ & $72(96.0)$ & $4(5.3)$ & $\begin{array}{l}71 \\
(94.7)\end{array}$ \\
\hline 3 & $\begin{array}{l}\text { I do not have money to buy sanitary pad } \\
\text { always, so sometimes I use other materials }\end{array}$ & $6(8.0)$ & $69(92.0)$ & $\begin{array}{l}16 \\
(21.3)\end{array}$ & $\begin{array}{l}59 \\
(78.7)\end{array}$ \\
\hline
\end{tabular}




\begin{tabular}{|l|l|l|l|l|l|}
\hline 4 & $\begin{array}{l}\text { There are no conducive facilities in my } \\
\text { school to enable me change regularly }\end{array}$ & $\begin{array}{l}10 \\
(13.3)\end{array}$ & $65(86.7)$ & $\begin{array}{l}44 \\
(58.7)\end{array}$ & $\begin{array}{l}31 \\
(41.3)\end{array}$ \\
\hline 5 & $\begin{array}{l}\text { My religion forbids me from attending } \\
\text { mosque, church or school when I am } \\
\text { menstruating }\end{array}$ & $4(5.3)$ & $71(94.7)$ & $\begin{array}{l}32 \\
(42.7)\end{array}$ & $\begin{array}{l}43 \\
(57.3)\end{array}$ \\
\hline
\end{tabular}

Table 5 presents factors that affect menstrual hygiene practices. The results show that conducive facilities was the major factor that affected menstrual hygiene practices.

\section{Answering research questions}

Research Question One: What is the level of awareness of menstrual hygiene among adolescent girls?

Table 6.1: Level of awareness of menstrual hygiene in RHS

\begin{tabular}{|l|l|l|l|l|}
\hline Awareness & Frequency & \% & Mean & SD \\
\cline { 1 - 3 } Low $(0-3)$ & 3 & 4 & 4.81 & 0.12 \\
\cline { 1 - 3 } High (4-6) & 72 & 96 & & \\
\cline { 1 - 3 } Total & 75 & 100 & & \\
\hline
\end{tabular}

Table 6.1 indicated that students scored high on awareness of menstrual hygiene $(\mathrm{M}=4.81$, $\mathrm{SD}=0.12$ ) implying that they have high awareness of menstrual hygiene in RHS.

Table 6.2: Level of awareness of menstrual hygiene in BUHS

\begin{tabular}{|l|l|l|l|l|}
\hline Awareness & Frequency & \% & Mean & SD \\
\hline Low (0-3) & 4 & 5.3 & 4.79 & 0.13 \\
High (4-6) & 71 & 94.6 & & \\
\cline { 1 - 2 } Total & 75 & 100 & & \\
\cline { 1 - 2 }
\end{tabular}

Table 6.2 indicated that students scored high on awareness of menstrual hygiene $(M=4.79$, $\mathrm{SD}=0.13$ ) implying that they have high awareness of menstrual hygiene in BUHS.

Research Question Two: What are the menstrual hygiene practices of adolescent girls in private schools and that of public schools? 
The result from table 4 showed that students in BUHS (81.35\%) and in RHS (90.7\%) used sanitary pads during their periods and took their baths mostly two times to three times when menstruating. Most of them disposed used menstrual materials by burning and majority often bought and used menstrual materials every month. Overall, moderate practice of menstrual hygiene was identified among the participants.

Research Question Three: What are the factors affecting menstrual hygiene practices among adolescent girls in senior secondary schools?

From table 5, it can be deduced that conducive facilities was the major factor that affected menstrual hygiene practices among the study participants, especially in BUHS.

\section{Hypotheses Testing}

Hypothesis One: There is no significant relationship between awareness of menstrual hygiene and its practices among adolescent girls.

Table 9: Pearson Product Moment Correlation Analysis of awareness of menstrual hygiene and its practice of menstrual hygiene

\begin{tabular}{|l|c|l|l|l|l|l|}
\hline Variables & N & Mean & S.D & R & Sig. & Remark \\
\hline $\begin{array}{l}\text { Awareness of menstrual } \\
\text { hygiene }\end{array}$ & 150 & 1.8011 & 0.12318 & \multirow{2}{*}{0.022} & .790 & $\begin{array}{l}\text { Not } \\
\text { significant }\end{array}$ \\
\hline $\begin{array}{l}\text { Practice of menstrual } \\
\text { hygiene }\end{array}$ & 150 & 1.2285 & 0.07548 & & \\
\hline
\end{tabular}

As shown in Table 9, there is no significant positive relationship between knowledge of menstrual hygiene and practices of menstrual hygiene among adolescent girls in private schools and those in public schools $(\mathrm{r}=.022, p>.01)$. Therefore, the hypothesis that there is no significant relationship between knowledge of menstrual hygiene and its practices among adolescent girls in private schools and those in public schools is accepted.

Hypothesis Two: There is no significant difference in the practice of menstrual hygiene among adolescent girls based on type of school (private and public schools).

Table 10: T-Test showing the Mean Difference between private and public adolescent girls on practice of menstrual hygiene

\begin{tabular}{|l|l|l|l|l|l|l|l|l|}
\hline Name of school & N & Mean & $\begin{array}{c}\text { Std. } \\
\text { Deviation }\end{array}$ & Df & $\begin{array}{l}\text { Mean } \\
\text { Diff. }\end{array}$ & \multicolumn{1}{|c|}{ T } & Sig. & Remark \\
\hline Remo secondary & 7 & 1.239 & 0.07802 & 14 & 0.0214 & 1.75 & 0.08 & Not sig. \\
school & 5 & 3 & & 8 & 8 & 5 & 1 & \\
\cline { 1 - 4 } & 7 & 1.217 & 0.07178 & & & & & \\
high school & 5 & 8 & & & & & & \\
\hline
\end{tabular}

The result in Table 10 shows that a significant difference does not exist between adolescent girls in private and public schools on practice of menstrual hygiene with mean values of 1.2393 and 1.2178 for adolescent girls in RHS and BUHS respectively. The mean difference between 
the two groups is 0.02148 . An independent t-test shows that the difference between the groups is not significant $(\mathrm{t}=1.755, \mathrm{df}=148, p=0.081)$. Therefore, the hypothesis that there is no significant difference in the practice of menstrual hygiene among adolescent girls based on type of school is accepted.

\section{DISCUSSION}

Findings from this study showed that the majority (58.7\%) of the respondents were between 15 and 17 years of age. 20.7\% were in SSS1 and SSS2 respectively, and 58.7\% were in SS3. $50 \%$ of the adolescent girls were from RHS and the 50\% left were from BUHS. Majority of their parents were vocational workers. Majority (96\%) of the respondents reported that they had started their periods. Findings from the result revealed that majority (96\%) of the respondents were very much aware and knowledgeable of what menstrual hygiene entails as compared to a similar study done by Priya, Kumari \& Meena (2019) where $61 \%$ had moderate knowledge on menstrual hygiene; Yadav Joshi, Poudel \& Pandeya (2018) revealed that $67.4 \%$ had fair knowledge and $26.4 \%$ had a good knowledge.

Findings from the study also revealed that respondents had a good practice of menstrual hygiene, which is in line with the study conducted by Asha, Karim, Bakhtiar and Rahaman (2019) where $67.8 \%$ of the respondents had a good practice of menstrual hygiene.

Results also showed that lack of conducive facilities in school (36\%) and religion (24\%) were major factors affecting menstrual hygiene practices. This corroborates the study of Kaur, (2019) where $67.6 \%$ of the respondents did not attend religious programmes during menstruation, 9.9\% did not attend school during menstruation and 58.67\% didn't participate in play activities during menstruation. This result is in line with Asha, Karim, Bakhtiar \& Rahaman, (2019) where lack of gender-specific toilets and water supply affects menstrual hygiene management, leading to poor physical and psychological health outcomes. In a study in Bangladesh, it was found that the absence of an available gender-specific toilet was one reason for school absence during menstruation (Alam et al., 2017).

\section{CONCLUSION AND RECOMMENDATIONS}

The study found out that adolescent girls in BUHS and RHS had high knowledge of menstrual hygiene and they had moderate practice of menstrual hygiene, but there were factors like religion and lack of conducive facilities affecting the effective practices among adolescent girls. Thus, the hypotheses established the fact that there was no relationship between awareness of menstrual hygiene and its practices among adolescent girls in private schools and those in public schools. Also, there was no significant difference in the practice of menstrual hygiene among adolescent girls based on type of school (private and public schools). And lastly, there was a significant influence of factors affecting menstrual hygiene on the practice of menstrual hygiene among adolescent girls.

It is recommended that information on safe hygiene and sanitary practices should be included in the school curriculum, and that there should be better communication between female students and their teachers as well as between daughters and mothers. Also, the school 
administration should provide adolescent girls more conducive and appealing facilities for them to practice good menstrual hygiene.

\section{REFERENCES}

Ahmed, R., \& Yesmin, K. (2008). Menstrual hygiene: breaking the silence. Beyond construction: Use by all. A collection of case studies from sanitation and hygiene promotion practitioners in South Asia. London: WaterAid, 283-287

Alam, M. U., Luby, S. P., Halder, A. K., Islam, K., Opel, A., Shoab, A. K., ... \& Unicomb, L. (2017). Menstrual hygiene management among Bangladeshi adolescent schoolgirls and risk factors affecting school absence: results from a cross-sectional survey. BMJ open, 7(7), e015508

Asha, A. C., Karim, N. B., Bakhtiar, M., \& Rahaman, K. S. (2019). Adolescent athlete's knowledge, attitude and practices about menstrual hygiene management (MHM) in BKSP, Bangladesh. Asian Journal of Medical and Biological Research, 5(2), 126-137

Dasgupta, A., \& Sarkar, M. (2008). Menstrual hygiene: how hygienic is the adolescent girl? Indian journal of community medicine: official publication of Indian Association of Preventive \& Social Medicine, 33(2)

Guterman, M., Mehta, P., \& Gibbs, M. (2008). Menstrual taboos among major religions. The Internet Journal of World Health and Societal Politics, 5(2)

Kamaljit, K., Arora, B., Singh, K. G., \& Neki, N. S. (2012). Social beliefs and practices associated with menstrual hygiene among adolescent girls of Amritsar, Punjab, India. JIMSA, 25(2), 69-70

Kamath R, Ghosh D, Lena A, Chandrasekaran, V. (2013). A Study On Knowledge And Practices Regarding Menstrual Hygiene Among Rural And Urban Adolescent Girls In Udupi Taluk, Manipal, India. Global Journal of Medicine and Public Health, 2(4)

Kaur, S. (2019). Knowledge and attitude on menstrual hygiene among adolescent girls in Kapurthala district of Punjab. Int. J. Sci. Res. Rev, 7, 3374-3379

Lawan, Nafisa \&Aisha. (2010). Menstruation and Menstrual Hygiene amongst Adolescent School Girls in Kano, Northwestern Nigeria. African Journal of Reproductive Health (Regular Issue), 14(3). Pp. 201- 206

Lawan, U.M., Nafisa, W.Y. \& Aisha B. M., (2010). Menstrauation and Menstrual Hygiene Among Adolescent School Girls in Kano, North-Western Nigeria. African Journal of Reproductive Health, 14(3), 201-207

Loughborough University, 2012. Developing knowledge and capacity in water and sanitation; Menstruation hygiene management for schoolgirls in low-income countries. 2012. Available:http://wedc.lboro.ac.uk/resources/factsheets/FS007_MHM_A4_Pages.pdf

Mudey, A. B., Kesharwani, N., Mudey, G. A., \& Goyal, R. C. (2010). A cross-sectional study on awareness regarding safe and hygienic practices amongst school going adolescent girls in rural area of Wardha District, India. Global Journal of Health Science, 2(2), 225

Nkandi. O. (2011). Menstruation and Menstrual Hygiene among Women and Young Females in Rural Eastern Nigeria. Retrieved from www.stanonline.org/journal/pdf/JSTANNkadi\%202011.pdf

Priya, D. B., Kumari, A., \& Meena, J. M. (2019). A Study to Assess the Knowledge on Menstrual Hygiene among Adolescent Girls in Selected Schools, Mangalagiri, Guntur District, Andhra Pradesh. International Journal of Nursing Education, 11(4), 35-38 
Shanbhag, D., Shilpa, R., D'Souza, N., Josephine, P., Singh, J., \& Goud, B. R. (2012). Perceptions regarding menstruation and practices during menstrual cycles among high school going adolescent girls in resource limited settings around Bangalore city, Karnataka, India. International Journal of Collaborative Research on Internal Medicine \& Public Health, 4(7), 1353

Uzochukwu, U.A., Patricia, N.A., Theophilus, 0.N. (2009). The impact of pre-menarcheal training on menstrual practices and hygiene of Nigerian school girls. Pan Afr. Med.J. 22:9.

Uzoma Aniebue, U. Z., Nonyelum Aniebue, P., \& Ogochukwu Nwankwo, T. (2009). The impact of premenarcheal training on menstrual practices and hygiene of Nigerianschool girls. Pan African Medical Journal, 2(9), 1-9

WaterAid -Kathmandu (2009). Is menstrual hygiene and management an issue for adolescent school girls- A comparative study of four schools in different settings of Nepal. Report Water-Aid in Nepal Publication. Pp. 1-32

WaterAid Report (2013). Menstrual Hygiene Matters: A Resource for Improving Menstrual Hygiene around the World

Yadav, R. N., Joshi, S., Poudel, R., \& Pandeya, P. (2017). Knowledge, attitude, and practice on menstrual hygiene management among school adolescents. Journal of Nepal Health Research Council, 15(3), 212-216 